\title{
USING COOPERATIVE LEARNING IN TEACHING CRITICAL THINKING IN READING
}

\author{
Anit Pranita Devi \\ Department of English Education, Indonesia University of Education, Indonesia \\ E-mail: anit.pranita.d@gmail.com \\ Bachrudin Musthafa \\ Department of English Education, Indonesia University of Education, Indonesia \\ E-mail: dinmusthafa@yahoo.com \\ Gin Gin Gustine \\ Department of English Education, Indonesia University of Education, Indonesia \\ E-mail: ggg@deakin.edu.au
}

APA Citation: Devi, A. P., Musthafa, B., \& Gustine, G. G. (2015). Using cooperative learning in teaching critical thinking in reading. English Review: Journal of English Education, 4(1), 1-14

Received: 16-02-2015

Accepted: 01-04-2015

Published: 01-12-2015

\begin{abstract}
:
This study investigates how cooperative learning facilitates students in learning critical thinking in reading and to find out the benefits and challenges during the implementation of cooperative learning in one vocational school in Cimahi. A case study is utilized by using instruments of classroom observations, questionnaires, semi structured interview and students' written tests. The findings show that the implementation of cooperative learning facilitates students develop their critical thinking and enhance critical thinking dispositions in reading. Three features which contribute to the development of students' critical thinking in reading are: the encouragement of student-student interaction; the provision of group purposes; and the provision of stimulus to the students' development of thought and ideas. The aforementioned features promote benefits which involved higher motivation and involvement, increased opportunity for language use, and developed interpersonal relationship. Nevertheless, these benefits are constrained by the availability of time, students' English proficiency, and students' contribution to the groupwork. It is recommended that further researchers conduct the similar study in a longer period to make sure that the key elements of cooperative learning are well-structured.
\end{abstract}

Keywords: cooperative learning, critical thinking

In this $21^{\text {st }}$ century as the age of information technology, there is a significant requirement of critical thinking skills in selecting and evaluating the reliability of the information (Halpern, 1999; see also Grabau, 2007; Oliver \& Utermohlen, 2007). The ability to think critically is also considered essential in a democratic society (Beyer, 1985) and thus pertinent in Indonesia in which democratic era is now encountered. However, based on research, South-East Asian (including Indonesian) students are considered lacking of critical thinking skills and unaware of the importance of skills of analysis and critiques (Egege \& Kutieleh, 2004; Djiwandono, 2013 \& Wallace, 2003). This might be due to the 
fact that the basic skills essential to critical thinking is not typically taught in schools.

Therefore, questions on the subject of how to teach critical thinking skills in reading have been queried. Since years ago, cooperative activities have been used for developing learners' critical thinking (Sharan, 1980). From an extensive literature review, it is found that cooperative learning is beneficial not only for developing students' language acquisition, academic achievement, and social skills, but also may foster critical thinking skills (Ghaith, 2003; Sadeghi, 2012). This is linked to the characteristic of instruction that can improve critical thinking which promotes studentstudent interaction (see Ten Dam \& Volman, 2004). The essence of this interaction for learning is obviously approved by Sharan (1980, p. 242) who states that "through the medium of this interaction and communication process within small groups cooperating on academic tasks that these team-learning methods strive to influence pupils' cognitive learning" (see also Fahim \& Eslamdoost, 2014). In this sense, cooperative learning which promotes greater interaction between students (Webb, 1982) has been frequently used to foster students' critical thinking (Cooper, 1995; Johnson, Johnson \& Smith, 1991; Sharan, 1980).

In line with the aforementioned statement, Bligh (1986) mentions that discussing in groups is effective to stimulate thoughts and develop ideas (cited in Dennick \& Exley, 1998). Further, Dennick \& Exley (1998) affirm that working in cooperative groups allow students to share divergent point of views, discuss ideas and communicate an issue with their peers. These activities could lead students to enhance their thought and ideas.
Moreover, Elder \& Paul (2001) suggest a way to help students develop their critical thinking skills by introducing the idea about "purpose" into their classroom experiences since they believe that "critical thinking is thinking to some purpose". It seems to be relevant to cooperative learning since when the students work in cooperative learning groups, they have group purpose to be achieved e.g. to make decision on the best response to the teacher's questions. From this point of view, cooperative learning tasks may be one of the ways in developing students' critical thinking as the students work in cooperative learning groups to achieve same goals. It is also supported by Paul (1995) that many students do not read well because they do not think deeply about the purpose or the logic of it.

Specifically speaking, cooperative learning refers to the classroom instruction that involves students working in small groups to achieve same goals and optimize their own and each other's learning (Brown, 2001; Johnson \& Johnson, 1999). However, cooperative learning is not simply making students work together in groups (Jacobs \& Hall, 2002; Johnson \& Johnson, 1999; Murray \& Christinson, 2010). There are several key elements that make cooperative learning groups different from other types of group work. The elements need to be fulfilled. to implement a successful cooperative learning. These elements are (Johnson, Johnson, Holubec \& Roy, 1984; Jollife, 2007; Johnson \& Johnson, 1999; Johnson \& Johnson, 2009a; see also Sadeghi, 2012):

1. Positive interdependence exists when there is a positive correlation among individuals' goal attainments; individuals perceive that they can attain their goals if and only if the other individuals with whom they are 
cooperatively linked attain their goals" (Johnson \& Johnson, 2009a, p.

366). Positive interdependence can be established through mutual goals, division of task, division of materials, assigning roles, and giving joint rewards (Johnson, Johnson, Holubec \& Roy, 1984).

2. Face-to face (promotive) interaction occurs when students are taking action in responsible and honest ways, giving help and positive influence to other group members and making effort effectively to gain benefit and shared goals, providing feedback each other to improve their performance, challenging each other's reasoning and conclusion, and exploring different perspectives of others. Johnson \& Johnson (2009a)

3. Individual and group accountability means that the members of a group learn together (Slavin, 1988; Johnson \& Johnson, 2000; see also Ning, 2011) but they actually perform individually so that they are responsible for their own learning. To build this key element, teacher can use three methods (Johnson, et al., 1984; Johnson, Johnson, \& Smith, 1998): providing individual test for the students; selecting randomly group members to present their group's response to a question orally; and giving opportunity for student to present what they have learned to a classmate.

4. Interpersonal and small group social skills exist when students learn how to work effectively in a group which has students with different level of knowledge and learning styles. They should have skills in leadership, decision-making, trust building and conflict management (Ghaith, 2001; see also Johnson \& Johnson, 2009a; Sadeghi, 2012).
5. Group processing takes place when group members are given time and procedure to evaluate the groupwork process that include deciding which actions were supportive and unsupportive and which actions to carry on or change (Johnson \& Johnson, 2009a; see also Johnson \& Johnson, 1999).

Through the five key elements of cooperative learning, students' critical thinking could be facilitated. As a matter of fact, cooperative learning promotes critical thinking through dialogical instruction in which students are involved in a dialogue by arguing on different points of view (see Paul, 1995). Students have a lot of opportunities to brainstorm their insights and ideas, to express different points of view, to synthesize different information and to evaluate the solution. At the same time, discussing in cooperative groups also assist them become better listeners, speakers, readers, and writers. In this sense, cooperative learning has significant influence on the development of critical thinking. Students could enhance their critical thinking as they share their learning in discussion and take responsibility for their own learning (Totten, Sills, Digby, \& Russ, 1991, cited in Gokhale, 1995).

With respect to critical thinking term, it is defined in many ways. One of the most eminent definitions of critical thinking is mentioned by Ennis (1991, p. 6). He defines critical thinking as "reasonable reflective thinking that is focused on deciding what to believe or do" (see also Ennis, 2011). He mentions that critical thinking, here, includes acts such as formulating hypotheses, different perspectives of viewing a problem, questions, possible solutions, and plans for examining something. 
From another point of view, Ryan (2003) suggests a definition of critical thinking as "the ability to collect, judge, and ultimately use information in an effective manner" (p.170). This includes analysis, synthesis, and evaluation. This statement is in the same vein with what Reichenbach (2001, p.19) states that critical thinking is "the careful, deliberate determination of whether we should accept, reject, or suspend judgment about the truth of a claim or a recommendation to act in a certain way". He mentions that it involves reasoning, reflection, and being practical.

In the light of the aforementioned explanation about the definition of critical thinking from some experts, it can be affirmed that critical thinking is ability to identify, analyze, synthesize, examine, communicate and evaluate ideas in effective manner to make decision about what to believe or do.

From that point of view, the concept of critical thinking seems to be relevant to the cooperative learning since cooperative learning activities may assist students to develop their critical thinking by having same group purpose, identify and analyze plenty of ideas from other group members, deciding important information for their groups, making decision of their group's agreement, synthesizing information, and changing perspectives in the groups to make decision.

Furthermore, critical thinking also involves particular dispositions (Ennis, 1991; 1996; 2011; Reichenbach, 2001; Emilia, 2005). "A disposition is a tendency to act or think in a certain way" (Reichenbach, 2001, p.14). This study focuses on six critical thinking dispositions which mainly proposed by Ennis (1991; 1996), Reichenbach, (2001), and Chaffee (2009) namely: 1) be openminded; consider other points of view than their own; (Ennis, 1991; 1996; Reichenbach, 2001); 2) take and change position when evidences are sufficient (Ennis, 1991; 1996; Reichenbach, 2001); 3) care to understand and present a position honestly and clearly including to discover and listen to others' view and reasons, be clear about the intended meaning of what is said, written, or otherwise communicated (Ennis, 2011); 4) take into account others' feelings and level of understanding (Ennis, 2011); 5) view situations from different perspectives (Chaffee, 2009; Cottrell, 2005); and 6) identify the argument and communicate author's intended meaning of what is said and what is written (Chaffee, 2009).

\section{METHOD}

This study was aimed to answer two research questions:

1) How does the implementation of cooperative learning facilitate students in learning critical thinking in reading?

2) What are the benefits and challenges of the implementation of cooperative learning?

This study employs qualitative case study design. A case study design has been considered appropriate, as this study, in line with one main characteristic of a case study, is concerned with a case on the implementation of cooperative learning in teaching critical thinking in reading and the benefits and challenges found in the implementation of cooperative learning. Moreover, like a case study, this study is carried out to investigate one particular instance of education (Merriam, 1988; Nunan, 1992) which is an eleventh grade classroom of English in a state vocational school in Cimahi, West Java. The classroom has 33 students as participants of this study. Regarding 
ENGLISH REVIEW: Journal of English Education Vol. 4, Issue 1, December 2015
ISSN 2301-7554

https://journal.uniku.ac.id/index.php/ERJEE the choice of the level, secondary level, it seems appropriate because the students will already have basic critical thinking skills from the perspective that they have more conceptual thinking than young learners do.

The students were given treatment of three types of cooperative learning techniques (Think-Pair-Share, Jigsaw, and structured controversy) in six sessions and their critical thinking in reading was examined by critical reading tasks. These three techniques were used in order to represent the basic principles of cooperative learning mentioned previously and in conjunction with their benefits in developing students' critical thinking in reading based on previous studies. Triangulation technique by means of classroom observation, questionnaire, semi-structured interview with participants, and students' written tasks were employed for collecting the data in this study. Classroom observation was employed to gain data about the process of cooperative learning implementation in the classroom and to assure that the five principles of cooperative learning are conducted. The close-ended questionnaire was intended to find out the students' point of view regarding the benefits and challenges of cooperative learning. Interview was employed to elicit students' opinions about the effects of cooperative learning on their critical thinking in reading and the benefits and challenges of cooperative learning in their perspectives. Students' written tests were employed to find out whether there is improvement of students' critical thinking

\section{RESULTS AND DISCUSSION}

The implementation of cooperative learning in facilitating students' critical thinking

In respect of the first research question, the result of data collection showed that students benefitted from the implementation of cooperative learning techniques used in this study since the three techniques (Think-Pair-Share, Jigsaw, Structured Controversy) helped them develop critical thinking and promote critical thinking dispositions in reading through the steps and through the five key elements of cooperative learning. The dispositions which are appeared and promoted in this study were be open-minded, consider other points of view than their own; take and change position when evidences are sufficient; present a position honestly and clearly; take into account others' feelings and level of understanding; and view situations from different perspectives.

Cooperative learning elements in facilitating students' critical thinking

Positive interdependence

Positive interdependence was built mainly by role interdependence, resource/material interdependence, and goal interdependence. In Think-PairShare technique, it was established by assigning different roles (roles interdependence) for students (e.g. as problem solver and listener). In Jigsaw technique, it was structured by dividing materials to the group members (materials interdependence). Meanwhile in structured controversy, it was established when students were given different texts regarding one topic (materials interdependence). Goal interdependence was structured in the implementation of the three techniques by giving mutual goal for each group. The mutual goal in this context was to answer the teacher questions regarding the texts given or to write a group report containing the group's agreement based on the discussion. By structuring positive interdependence, the students 
actively participated in the group discussions and were responsible for learning the materials. From the interview with the students, it was also found that all students contributed to the work of the cooperative group which automatically makes all students involved. This is in line with Ryan (2003) who states that the development of students' critical thinking can be promoted by leading the students to actively engage and involve in classroom activities.

\section{Face-to-face promotive interaction}

Face-to-face promotive interaction was established in the lesson by giving mutual goal for every group so that they could discuss their ideas to support and assist each other on the topic in their efforts in learning and to achieve their shared goal (Johnson et al., 1991; Johnson \& Johnson, 2009a). Providing group purpose could bring promotive interaction out as well as promote students' critical thinking. This is in line with a suggestion from Elder \& Paul (2001) that a way to help students develop their critical thinking skills is to introduce the idea about "purpose" into their classroom experiences since they believe that "critical thinking is thinking to some purpose". In the discussion process, it could be seen from the observation that each member of the group supported and assisted each other in their efforts in learning the topic and in achieving the same goal (Johnson \& Johnson, 2009a).

In Think-Pair-Share, the mutual goal was to answer the teacher's questions and to meet an agreement about the best response or solution to the teacher's questions. In Jigsaw, the mutual goal was that each member of the group had to understand the divided text so that all members tried to teach each other by explaining the materials clearly. Meanwhile in structured controversy, the group goal was to meet a consensus and the best agreement with the justification in the end of the controversy activity. In the process of cooperative group discussion to achieve the mutual goal, the students tried to give help and positive influence to other group members and made effort effectively to gain benefit and shared goals, provided feedback each other, challenged each other's reasoning and conclusion, and explored others' different perspectives.

\section{Individual accountability}

This element was built by giving the students individual task. Individual accountability would be established when each individual performance is assessed (Johnson \& Johnson, 2009a). Furthermore, to increase individual accountability, the students were asked to jot down their ideas before turning to a partner and discussing the ideas. The importance of taking notes from the critical thinking point is to foster students' metacognition or the control of their own thinking (Costa, 2003 as cited in Emilia, 2005). By structuring this element, each student was actively engaged in the discussions and contributed to the groupwork.

\section{Small group and interpersonal skills Small group and interpersonal} skills element was built when the students were discussing and sharing ideas. Students learned how to work effectively in a group which has different students with different level of proficiency and ideas. In the discussion process, the students learned to listen carefully and critically to each other in presenting their point of views and taking turns in presenting ideas. The 
ENGLISH REVIEW: Journal of English Education Vol. 4, Issue 1, December 2015
ISSN 2301-7554

https://journal.uniku.ac.id/index.php/ERJEE skills are essential in facilitating the student's critical thinking development since a critical thinker has to see an issue not only from one single perspective but from multiple perspectives (Chaffee, 2009).

Other than that, in the discussion to achieve their shared goal, the students also used their interpersonal and social skills such as decision-making which appeared when they decided to choose the best answer to the teacher questions and also conflict management when they have different opinion regarding the issue being discussed (Ghaith, 2001; see also Johnson \& Johnson, 2009a; Sadeghi, 2012). This element was also structured when students challenged each other's perspective and defending their own position. They learned how to agree with another's ideas.

\section{Group processing}

This key element was established by giving the students time to write a reflective learning journal regarding things they learned from the teacher, from their friends, and from the groupwork, and things they need to improve (Kagan \& Kagan, 2009). This element was essential for students to practice students' critical thinking particularly on critical evaluation. It was also revealed that students' critical thinking was developed gradually in every meeting evidenced by the quality of students' responses in the reflective form.

The assistance to students' critical thinking

It was revealed that the assistance of students' critical thinking in reading development was achieved through three ways.
The encouragement of student-student interaction

One of characteristics of instruction that can improve critical thinking is one which promotes student-student interaction that (Sharan, 1980; Ten Dam \& Volman, 2004; see also Fahim \& Eslamdoost, 2014). In this study, the cooperative learning techniques (ThinkPair-Share, Jigsaw, and structured controversy) were found effective in increasing the interaction between students. Interaction between students was increased when they had more opportunities to share with peers, when they accomplished task together and when they expressed their ideas and share what they had learned to their friends. Accordingly, the active participation of the students was also enhanced.

In Think-Pair-Share, for example, the students had to share their thoughts on the given questions with their pairs before sharing to the whole class. This kind of interaction can help to sharpen their thinking and problem solving skills. Furthermore, in structured controversy technique, the students interacted when they learned their position with their partner, presented their position to the opposing view, discussed the issue, and reached a decision for their group. In these interactions, conflict among their ideas, opinions, perspectives and conclusions are unavoidable and further could enhance students' thinking skills (Johnson \& Johnson, 1993; see also Johnson \& Johnson, 1988). The following interview excerpts show that the students felt their active participation and critical thinking were improved. 
S1: We participated more actively so I could solve the problems.

S2: In my opinion, I was more active. Because we had our own role.

The excerpt illustrates that cooperative learning gave the student opportunity to participate actively in classroom instruction since all students were given roles.

\section{The provision of group purpose}

As mentioned previously, one of characteristic of instruction which can foster students' critical thinking is providing purposes. In cooperative learning, every cooperative group has its own mutual goal such as making decision on the best answer or responses to the teacher question, writing group report regarding group position on the issue being discussed. In this context, the teacher structured the cooperative instruction so that the students were aware of their common goals. The following example was taken from students' reflective learning journal.

\footnotetext{
I have learned to collaborate with my group, even though my group divided by two, we must respect to our opponent in debate. After we do the debate, we must find the conclusion and become one group again. I think it is fun and make solid the group.
}

The excerpt above illustrated that the student was aware of the goal of the group which was to find the conclusion and to meet an agreement in the group even though they had to argue and attack each other's ideas beforehand.

The stimulus to the development of thought and ideas

Students who are engaging in cooperative learning lesson will be stimulated to develop their thinking (see Johnson \& Johnson, 1988; 1993). Bligh (1986) mention that discussing in groups is effective to stimulate thoughts and develop ideas (cited in Dennick \& Exley, 1998). The development of thought and ideas in cooperative learning is inevitable. In this study, students were encouraged to develop their ideas as the students interacted, shared opinions, solved problems, synthesized information, rebutted position, questioned different perspectives, and made decision on an issue. From the questionnaire, $100 \%$ of the students stated that their thinking and development of ideas were honed through cooperative learning techniques. In addition to that, by listening to other's ideas on an issue, the stimulus to the development of ideas was also increased since the students were able to see other alternatives of solving a problem or respond to a question. In this view, the students could also refine their thinking and decision making. It was also reported from the questionnaire that $86 \%$ of students thought that cooperative learning techniques could develop their problem-solving skills and $90 \%$ of the students stated that they also could develop their decision making skills through cooperative learning. It could be confirmed by students' statement from the interview.

$$
\begin{aligned}
& \text { S4: In my opinion, in the groupwork, we could } \\
& \text { be braver to express or give opinions based } \\
& \text { on our thought. We were able to know } \\
& \text { other's perspectives. So we do not see an } \\
& \text { issue from only one side) } \\
& \text { S5: ... we could understand other's view point } \\
& \text { on an issue }
\end{aligned}
$$

Finally, $95 \%$ of the students stated that their critical thinking was also developed through cooperative learning techniques

\section{The result of students' written tests}

The students' written test was intended to reveal the development of students' critical thinking in reading. The 
students' written test involves pre-test and post-test. The students were given a text and they had to answer critical reading questions regarding the text. In calculating the data, paired T-test was employed to reveal the significance of the difference between the means of pretest and posttest. The following table shows the statistical computation of the scores.

Table 1

\begin{tabular}{|c|c|c|c|c|c|c|c|c|c|}
\hline \multicolumn{10}{|c|}{ Paired Samples Test } \\
\hline & & \multicolumn{5}{|c|}{ Paired Differences } & \multirow[t]{3}{*}{$\mathrm{t}$} & \multirow[t]{3}{*}{ df } & \multirow{3}{*}{$\begin{array}{l}\text { Sig. (2- } \\
\text { tailed) }\end{array}$} \\
\hline & & \multirow[t]{2}{*}{ Mean } & \multirow[t]{2}{*}{$\begin{array}{c}\text { Std. } \\
\text { Deviation }\end{array}$} & \multirow{2}{*}{$\begin{array}{l}\text { Std. } \\
\text { Error } \\
\text { Mean }\end{array}$} & \multicolumn{2}{|c|}{$\begin{array}{c}95 \% \text { Confidence Interval } \\
\text { of the Difference }\end{array}$} & & & \\
\hline & & & & & Lower & Upper & & & \\
\hline Pair 1 & $\begin{array}{l}\text { pretest - } \\
\text { posttest }\end{array}$ & -19.091 & 5.976 & 1.040 & -21.210 & -16.972 & -18.352 & 32 & .000 \\
\hline
\end{tabular}

The paired $t$-test, as presented in table 1 above, shows that there was difference between pretest and posttest scores for sig $0.00<0.05$. The $t$-value $(t=-$ 18.352, df. $=32, \mathrm{p}=.000$ ) was more than the alpha (.05). It indicates that the null hypothesis $\left(\mathrm{H}_{0}\right)$ was rejected, meaning that there was significant difference between the students' critical reading ability between pretest and posttest scores. In other words, the students' critical reading abilities were improved after the students were taught by using cooperative learning techniques.

However, the overall results of the statistical value could not be claimed as the effect of the instruction since this study only involved one single group and there was an absence of control group (Hatch and Farhady, 1982). The results of students' written tests were only used for descriptive purpose only, that is to show the description of how the cooperative learning techniques could facilitate students' critical reading abilities in general, not as the core of main findings to be exposed.

Nonetheless, to reduce the issue of the internal validity in this particular data, the research had employed multiple sources of data as discussed earlier. The figures appeared in the result of the written tests were not interpreted in isolation.

Benefits of and challenges to the implementation of cooperative learning In relation to the second research question, this study revealed that the implementation of cooperative learning had given some benefits and challenges.

\section{The benefits}

- Higher involvement and motivation

Based on the findings of this study, it was revealed that the students were more motivated in learning and involved more actively in the teaching learning process. Firstly, based on the questionnaires, $94 \%$ of students stated that they were more motivated in teaching learning process by cooperative learning techniques. Regarding this, all interviewees also thought that they were motivated by cooperative learning. Moreover, regarding students' active involvement, it was found from the questionnaire that $97 \%$ of the students stated that they had more active participation in cooperative learning lessons. These findings support numerous research studies which suggest that cooperative learning leads to higher motivation and active participation. (see Dorneiy, 1997; Johnson \& Johnson, 2009b). 


\section{Increased opportunity for language use}

Besides promoting higher

motivation and involvement, it was found that the implementation of three cooperative learning techniques was likely to increase the opportunity for students to use English. Based on the questionnaire, $97 \%$ of the students agreed that their language skills were improved in cooperative learning. This improvement was unavoidable since the students have to use English in the interaction in their groups.

In this context, the students not only practiced the language in reading but also in their language skills particularly speaking and listening. During their groupworks, the students were always encouraged to use English in their interaction. In addition to that, based on classroom observation, it was found that the students mostly used English in their interaction in the cooperative learning groups. In this sense, they speak, listen, read, and write in English during their interaction. Thus, the exposure to English is subsequently increased in the instruction. This interaction is useful for language learning since it contributes to second language acquisition (Pica, Young, \& Doughty, 1987).

\section{Developed interpersonal relationship}

The development of interpersonal relationships through cooperative learning can be established through building and maintaining friendship between peers and learning from others (Johnson \& Johnson, 1999). With respect of the development of interpersonal relationship, two main categories of interpersonal relationship were revealed. They were 1) maintaining groupwork by positive interdependence; and 2) listening and appreciating other's point of view. Based on questionnaire,
$97 \%$ of the students agreed that in cooperative learning, they always supported and helped each other in learning the material. This finding showed that the positive interdependence among them was built.

The challenges

Availability of time

The first challenge found in the implementation of cooperative learning was the time of learning. Based on the questionnaire, $69 \%$ of students stated that they lack of time in cooperative learning lesson. $100 \%$ of interviewee also confirmed this in the interview. In Indonesian vocational school, the time of learning English for tenth grade students is $2 \times 45$ minutes in a week. As a matter of fact, this time of learning was considered less to have students master all critical reading skills well.

\section{Students' English proficiency}

The second challenge in this study dealt with students' English proficiency. Four students in the interview admitted that the lack of language proficiency such as limited vocabularies, grammar, and pronunciation was their obstacle in the instruction. This challenge hindered the students in understanding the text comprehensively and in expressing their opinions.

\section{Students' contribution to the groupwork}

The third challenge dealt with the students' contribution to the work of the group. Students may not know what to do in their groups (Jacobs, 2006). Based on the questionnaire, $22 \%$ of the students stated that they did not know how to work in their groups. Furthermore, the students contributed little or nothing to the group work. This might happen due to unclear instruction from the teacher. Thus, it was also revealed that the 
ENGLISH REVIEW: Journal of English Education Vol. 4, Issue 1, December 2015
ISSN 2301-7554

https://journal.uniku.ac.id/index.php/ERJEE teacher's role as a facilitator has not been optimal since the teacher should facilitate students to work effectively in the groups.

\section{CONCLUSION}

On the basis of classroom observation, students' written tests, questionnaire and interview, the data indicated that, despite some limitations, the cooperative learning appeared to facilitate students' to learn critical thinking in reading and promoted students' critical thinking dispositions. The facilitated students' critical thinking dispositions were be open-minded, consider other points of view than their own; take and change position when evidences are sufficient; present a position honestly and clearly; take into account others' feelings and level of understanding; and view situations from different perspectives. Data from students' written tests also gave evidence that students' critical reading abilities improved during the teaching learning process in the classroom.

This study also revealed three features which contributed to students' critical thinking development. Firstly, the implementation of cooperative learning encouraged student-student interaction. Secondly, cooperative learning provided group purposes that the students could work in their groups and structured positive interdependence to achieve their common goals. Thirdly, the students' development of thought and ideas was also stimulated in the implementation of cooperative learning as they are engaging in discussions, sharing their thoughts and present their ideas.

Finally, it was also indicated in this study that the teacher's role as a facilitator in cooperative learning has not been optimal to get the students to work in groups effectively. There were still some unclear instructions that made some students confused about what to do and reluctant to contribute the work of the group. The limited time was also regarded to cause teacher's lack of monitoring. Due to the fact that the teacher had limited time to monitor all groups, some students also used their native language in the group discussion whereas they were encouraged to use English.

Based on the findings of this study, which may not be generalized to other settings, it is suggested for teachers that the teaching of cooperative learning and critical thinking is intensively implemented in all levels of study from primary to tertiary levels. For further researchers, it is suggested to conduct similar studies in longer period to make sure that the key elements of cooperative learning are well-structured and in larger scale to gain more various and detailed data.

\section{REFERENCES}

Beyer, B. K. (1985). Improving student thinking. Boston: Allyn and Bacon.

Brown, H. D. (2001). Teaching by principles: An interactive approach to language pedagogy (Second Edition.). White Plains, NY: Addison Wesley Longman, Inc.

Chaffee, J. (2009). Thinking critically. Wadsworth: Cengage Learning.

Cooper, J. L. (1995). Cooperative learning and critical thinking. Teaching of Psychology, 22(1), 7-9. http://dx.doi.org/10.1207/s15328023to p2201_2

Cottrell, S. (2005). Critical thinking skills: Developing effective analysis and argument. New York: Palgrave Macmillan

Dennick, R. G., \& Exley, K. (1998). Teaching and learning in groups and teams. Biochemical Education, 26(2), 111115. http://dx.doi.org/10.1016/S03074412(98)00028-4 
Djiwandono, P. I. (2013). Critical thinking skill for language students. TEFLIN Journal, 24(1), 32-47. Retrieved from http://journal.teflin.org/index.php/tefl in/article/view/320/258

Dörnyei, Z. (1997). Psychological processes in cooperative language learning: Group dynamics and motivation. The Modern Language Journal, 81(4), 482-493. http:/ / dx.doi.org/10.2307/328891

Egege, Y.S. \& Kutieleh, S. (2004). Critical thinking and International students: A marriage of necessity. Paper presented in First Year in Higher Education 2004 Conference: Dealing with Diversity. 8th Pacific Rim Conference, Melbourne. Retrieved from fyhe.com.au/past_papers/Papers04/05 0.doc

Elder, L. \& Paul, R. (2001). Critical thinking: Thinking to some purpose. Journal of Developmental Education, 25(1), 40-41. Retrieved from http:/ / search.proquest.com/docview / 2 28491079 ? accountid $=25704$

Emilia, E. (2005). A critical genre-based approach to teaching academic writing in a tertiary EFL context in Indonesia (Unpublished doctoral dissertation). Melbourne: University of Melbourne.

Ennis, R. (1991). Critical thinking: A streamlined conception. Teaching Philosophy, 14(1), 5-24. Retrieved from http:/ / www.criticalthinking.net/Ennis StreamConc1991\%20LowRes.pdf

Ennis, R.H. (1996). Critical thinking. New Jersey: Prentice Hall

Ennis, R. H. (2011). The nature of critical thinking: An outline of critical thinking dispositions and abilities. Retrieved from http:/ / faculty.education.illinois.edu/rh ennis/documents/TheNatureofCritical Thinking_51711_000.pdf

Fahim, M., \& Eslamdoost, S. (2014). Critical thinking: Frameworks and models for teaching. English Language Teaching, 7(7), 141-151. http://dx.doi.org/10.5539/elt.v7n7p141

Ghaith, G. (2003). Effects of the learning together model of cooperative learning on English as a foreign language reading achievement, academic selfesteem, and feelings of school alienation. Bilingual Research Journal, 27(3), 451-475.

http://dx.doi.org/10.1080/15235882.20 03.10162603

Gokhale, A. A. (1995). Collaborative learning enhances critical thinking. Journal of Technology Education, 7(1), 22-29.

Retrieved from http://scholar.lib.vt.edu/ejournals/JTE /v7n1/gokhale.jtev7n1.html?ref=Sawos.Org

Grabau, L.J. 2007. Effective teaching and learning strategies for critical thinking to foster cognitive development and transformational learning. Effective Teaching and Learning, 5, 123-156. Retrieved fromhttp://cpe.ky.gov/nr/rdonlyres/7 bab05e6-cacd-4395-83f80873e017ef4c/0/effective_teaching.pdf

Halpern, D. F. (1999). Teaching for critical thinking: Helping college students develop the skills and dispositions of a critical thinker. New Directions For Teaching And Learning, 80, 69-74.

Retrieved from http://www.precisionmi.com/precisio nmi/Materials/CollegeMat/criticalthin king-Halpern.pdf

Hatch, E. M. and Farhady, H. (1982). Research design and statistics for applied linguistics. Rowley, Massachusetts: Newbury House Publishers, Inc.

Jacobs, G. M. (2006). Issues in implementing cooperative learning. In McCafferty, $S$. G., Jacobs, G. M., \& Iddings, A. C. D., Cooperative learning and second language teaching (p. 18-29). New York, NY: Cambrige University Press.

Jacobs, G. M. \& Hall, S. (2002). Implementing cooperative learning. In Richards, J. C. \& Renandya, W. A. (Eds), Methodology in language teaching (pp. 52-58). New York, NY: Cambridge University Press.

Johnson, D. W., \& Johnson, R. T. (1999). Making cooperative learning work. Theory into Practice, 38(2), 67-73. http:/ /dx.doi.org/10.1080/00405849909 543834 
ENGLISH REVIEW: Journal of English Education Vol. 4, Issue 1, December 2015
ISSN 2301-7554

https://journal.uniku.ac.id/index.php/ERJEE
Johnson, R. T., \& Johnson, D. W. (2000). How can we put cooperative learning into practice? The Science Teacher, 67(1), 39. Retrieved from http:// search.proquest.com/docview/2 14621607? accountid $=25704$

Johnson, D. W., \& Johnson, R. T. (2009a). An educational psychology success story: Social interdependence theory and cooperative leraning. Educational Researcher, 38(5), 365-379. http://dx.doi.org/10.3102/0013189X09 339057

Johnson, D. W., \& Johnson, R. T. (2009b). Energizing learning: The instructional power of conflict. Educational Researcher, 38(1), 37-51. http://dx.doi.org/10.3102/0013189X08 330540

Johnson, D. W., Johnson, R. T., Holubec, E. J., \& Roy, P. (1984). Circles of learning: Cooperation in the classroom. Alexandria, VA: Association for Supervision and Curriculum Development.

Johnson, D. W., Johnson, R. T., \& Smith, K. A. (1991). Cooperative Learning: Increasing College Faculty Instructional Productivity. (ASHE-ERIC Higher Education Report No. 4). Washington, DC: The George Washington University, School of Education and Human Development. Johnson, D. W., Johnson, R. T., \& Smith, K. A. (1998). Cooperative learning returns to College: What evidence is there that is works? Change, 30(4), 26-35. http:/ / dx.doi.org/10.1080/00091389809602629

Jollife, W. (2007). Cooperative learning in the classroom: Putting it into practice. London, England: Paul Chapman Publishing.

Kagan, S. \& Kagan, M. (2009). Kagan cooperative learning. San Clemente, CA: Kagan Publishing.

Merriam, S. B. (1988). Case study research in education: A qualitative approach. San Fransisco, CA: Jossey-Bass.

Murray, D. E. \& Christinson, M. A. (2010). What English language teachers need to know. New York, NY: Routledge.

Ning, H. (2011). Adapting cooperative learning in tertiary ELT. ELT Journal, 65(1), 60-70. doi:10.1093/elt/ccq021
Nunan, D. (1992). Research methods in language learning. Cambridge, England: Cambridge University Press.

Oliver, H. \& Utermohlen, R. (1995). An innovative teaching strategy: Using critical thinking to give students a guide to the future. (Eric Document Reproduction Services No. 389 702)

Paul, R. W. (1995). Critical thinking: How to prepare students for a rapidly changing world. Santa Rosa, CA: Library of Congress.

Pica, T., Young, R., \& Doughty, C. (1987). The impact of interaction on comprehension. TESOL Quarterly, 21(4), 737-758.

Retrieved from: http://tesol.aua.am/TQD_2000/TQD_2 000/TQ_D2000/VOL_21_4.PDF\#page= 130

Reichenbach, B. R. (2001). Introduction to critical thinking. New York, NY: McGraw-Companies, Inc.

Ryan, M. (2003). Ask the teacher: A practitioner's guide to teaching and learning in the diverse classroom. Boston, MA: Pearson Education, Inc.

Sadeghi, M. R. (2012). The effects of cooperative learning on critical thinking in an academic context. Journal of Psychological and Educational Research, 20(2), 15-30. Retrieved from http:/ / search.proquest.com/docview/1 272063750? accountid $=25704$

Sharan, S. (1980). Cooperative learning in small groups: Recent methods and effects on achievement, attitudes, and ethnic relations. Review of Educational Research, 50(2), 241-271. http:/ /dx.doi.org/10.3102/00346543050 002241

Slavin, R. E. (1988). Cooperative learning and student achievement. The Education Digest, 54(6), 15. Retrieved from http:// search.proquest.com/docview/2 18167218? accountid $=25704$

Ten Dam, G., \& Volman, M. (2004). Critical thinking as a citizenship competence: teaching strategies. Learning and instruction, 14(4), 359-379. http://dx.doi.org/10.1016/j.learninstru c.2004.01.005 
Wallace, C. (2003). Critical reading in language education. New York, NY: Palgrave Macmillan Ltd.

Webb, N. M. (1982). Student interaction and learning in small groups. Review of
Educational Research, 52(3), 421-445.

http://dx.doi.org/10.3102/00346543052 003421 